\title{
Study on the Literature Review of University Teachers' Human Resources
}

\author{
Ningning Yan \\ School of Management and Economics, Jingdezhen Ceramic Institute, Jiangxi Province, China \\ Isemail2008@163.com
}

\begin{abstract}
Keywords: College teachers; University; Human resources; Literature review
\end{abstract}
\begin{abstract}
This paper summarizes the research direction and current status of teachers in colleges and universities in recent years in the field of human resources, found mainly in three aspects: teachers of university human resource allocation, management, development, the establishment of incentive mechanism and risk analysis; definition, value, value of human capital property rights of university teachers; teachers in colleges and universities human resource value measurement and the distribution of income, personal income and cost of investment in higher education. On this basis, this paper analyzes the existing problems in the research of human resource input and output efficiency of university teachers, and puts forward that the future research direction should focus on the comparison of college Teachers' professional superiority.
\end{abstract}

\section{Introduction}

The university is a national heritage classic, the dissemination of knowledge, talents training, an important base for innovation, various universities in recent years more and more attention to human resources management of university teachers, because teachers in colleges and universities human resources related to teaching and research is the key to success in an invincible position in the fierce competition in the socialist market economy system in colleges and universities. Since the human resources of colleges and universities is so important, the input and output efficiency is necessary for us to study the advantages of human resources of colleges and universities, college teachers of the occupation compared with other occupation and pay the opportunity cost. The effective research on this aspect is helpful to the development of human resources.

This review is based on the Chinese Journal Full-text Database Retrieval in recent years about the human resources of colleges and universities, University Teachers' cost of investment, human capital theory and the Mincerian rate of the article, and to our country in recent years the college teacher human resources input and output efficiency of research, the status quo and existing problems are analyzed. And discusses the future research direction.

\section{The Main Problems in the Research of University Teachers' Human Resources}

From the beginning of last century, Chinese scholars have done a lot of research university teachers human resource management, the human resources of colleges and universities, colleges and universities human resources, academic human resources literature search for keywords, found several main research directions of the college teacher human resources management, configuration, development, incentive mechanism, risk analysis. Guan Yunfei and [1] system summarizes the human resource management of University teachers. They divided the research into human resource management of colleges and universities into two topics: the research of problem and the research of countermeasures, and combed the related literature according to the two themes.

First, the concept of the human resource management of college teachers, the current research status and problems. They summed up the different stages, different scholars such as Song Jiajin, on behalf of the view, Wang Aiwu, Tian Zhilong, and Liu Jianxun white Ruizheng study and analysis of the present state of human resources management in colleges and Universities: leading high-end talent shortage, scientific research and teaching on the university teachers team age more no cohesion. In view of the above problems, we should avoid following the trend of recruitment, pay attention to the management 
of human resources of university teachers, select and develop, and correct the attitude of the rational and orderly flow of talents in colleges and universities. With the development of the research in this field and the application of the principle of combining theory with practice, the concept of human resource management is becoming more and more mature. At the same time, the concept of human resources has gradually become mature, the mode of management innovation of human resources of colleges and universities to introduce a competition called the mode of innovation, but also formed another mode of human resources management in universities is to encourage innovation mode. In addition, they also analyzed the problems unsolved: hard work and income is not proportional to the agreement on the concept of human resource management is too conservative, the human resources management staff is not perfect, the lack of incentives have a significant effect. After summing up the above problems, they put forward some specific suggestions and measures to improve the efficiency of human resource management in colleges and universities.

Two is the study of the relationship between human resources and social groups. This paper studies the relationship between human resource management and social groups in colleges and universities, and puts forward five relations theory. With the further development of the research, put forward several aspects of human resource management in colleges and universities still need to endeavor: the strengthening of university human resource management concept, selection of high quality human resources, strengthen management, to create a good environment for the growth of talent training mode, create talented establish incentive mechanism to implement the reward and punishment system, strengthen the cadres' self management.

The three is the human resources management system of colleges and universities. The scholars have carried on research and study from the theoretical sources, the university human resources management object characteristics, management cost, concept and practice characteristics, other scholars are still college teacher human resources cost analysis, connotation, value realization and value.

The four is the development of human resources in colleges and universities, performance evaluation, the innovation of human resources management model. According to the characteristics of human resources in colleges and universities, this paper indicates the guiding ideology and principle basis of the allocation of human resources in colleges and universities, and puts forward the steps and methods of the allocation of human resources in colleges and universities. At the same time, advocates the establishment of a sound performance appraisal mechanism. This paper puts forward the strategy to realize the innovation mode, which is to change the concept, improve the planning and optimize the environment.

\section{Research on Human Capital of University Teachers}

First of all, the property rights of human capital of university teachers to make the definition of university teachers human capital is formed by multi subject of investment, so should not the human resources of colleges and universities of all individuals but by multiple investors all together.

Secondly, the author thinks that the human capital investment in colleges and universities is the investment for the development and the development of human resources. This paper analyzes the reasons for the formation of investment risk, which is divided into external and internal reasons. Then they put forward specific precautions against the risks.

Thirdly, it is very important to establish and perfect the incentive mechanism of human capital in colleges and universities. Measures should be taken to improve the allocation of incentive mechanism, respect for the status of teachers, improve the culture of colleges and universities and the leader's incentive mechanism. This paper analyzes the objective function and the utility mechanism of the human capital motivation of university teachers, and puts forward the incentive mechanism and the realization measures of the university human capital value. This paper also studies the incentive methods of human capital property rights of teachers, and puts forward the method of salary incentive. 
Finally, the key to realize the increment of human capital of university teachers is the teachers themselves. The author thinks that the university should establish the concept of human capital management, establish and improve the introduction, competition, release and supervision mechanism of human capital value. This paper constructs a dynamic model of human capital value increase of university teachers, and puts forward some concrete strategies for the increase of human capital.

\section{Research on the Cost and Benefit of College Teachers' Human Resources Input}

The American economist Sherwin Rosen on education investment and occupation selection, research work and study selection problem in the labor market, enrich the theory of human capital, education and occupation, lay a theoretical foundation for research on the investment and occupation area.

Hu Shouzhong, Chu Juexi designed a set of the human capital measurement and incentive model, to fully mobilize the enthusiasm of teachers in colleges and universities. They analyzed the form of capital return of college Teachers' human capital, and measured the value of human capital.

Hu Qiuguang analyzes the costs and benefits of higher education investment, personal investment in higher education cost: direct costs; indirect cost, opportunity cost; risk cost; other costs. The income of individual higher education investment can be divided into monetary and non monetary benefits. Thunder, Andy Lau, Gregory also shows a similar point of view, put forward the education of individual investment cost - income discount after the balance point, is the individual education investment feasible decision point.

Hole green shows that higher education to enhance the human ability is very important, discusses the significance of higher education in the value of human capital increment, personal income and training activities for higher school personnel were analyzed to describe and model.

\section{The Research Direction of University Teachers' Human Resources}

From the research results summarized above can be seen, at present in the field of human resources of university teachers, university teachers mainly focus on the management of human resources, including human resources planning, development and problems of research, reform, establishing incentive mechanism etc. As for university teachers of human capital investment in training, focus on University Teachers' human capital property belonging, investment risk and risk prevention, value definition, value and value realization way. However, there is insufficient research on the efficiency of human resource input and output.

The American economist Sherwin Rosen from the human capital theory research, education and occupation selection problems, he analyzed the relationship between school education and future income, the results of this study can serve as a theoretical reference to human resource input and output of college teachers, but he only studied the personal education investment and future occupation income, occupation is various, did not focus on the occupation of university teachers, I believe that research on human resources input and output efficiency of university teachers should include two aspects: one is the investment in the calculation of university teachers should give up early choice to study the opportunity cost. The two is on the revenue side, college teachers of the occupation and occupation of other social comparison, comparison between the education investment in this occupation college teachers in return and other occupation may get the income of college teacher's pre. He also focuses on the relationship between work can provide learning opportunities and personnel selection work, or learning gains bring investment and work, popular talk is the future of work, it can also be used in the field of college Teachers' occupation. Hu Shouzhong Zhu Juexi, the distribution of its benefits is through the measurement of the value of human resources of colleges and universities to reasonable, and eventually achieve the incentive of university teachers, increase the stock of human capital, and did not touch the efficiency problem of college teacher human resources input and output, they are standing in the perspective of colleges instead of university teacher's perspective the. Hu Qiuguang, Andy Lau, Ge Yuhui, thunder, Kong Qing and others have studied the problem of cost and 
benefit of higher education investment, from a personal point of view, in my opinion, these studies explain the first research on human resource input and output efficiency of College Teachers in the university teachers to pay this occupation before the opportunity cost and the resulting returns, but far from involves second problems.

I think in the field now, most of them are standing in the angle of thinking about the problem, such as how to manage human resources, university teachers how to develop, how to motivate, how to avoid investment risks and so on, but ignore the college teachers from the starting point to solve the problem of human capital, occupation choice retention problem and the only research is personal, of personal investment in higher education brings to the individual future occupation career income, this income is for all occupation of society, not focusing on the college teachers of the occupation, but I just thought of research on human resource input and output efficiency of college teachers is the personal investment as a quantitative, the future occupation choice as a variable, to compare the relative to their occupation teachers in Colleges and Universities The superiority of his profession. Future research in this field should work in this direction.

\section{Acknowledgement}

This work was supported by the research subject of teaching reform in colleges and universities of Jiangxi province (JXJG-16-11-22/ JXJG-15-11-9).

\section{References}

[1] Guan, Chen Xiaohong. A review of human resource management in Chinese universities. Modern university education, 2009 (4): 83-87.

[2] Shu Yuxiang. University's human capital property right and the definition of value. Jiangsu higher education, 2003 (6): 115-117.

[3] Hao Jingxi. Definition and property rights of human capital of university teachers. Journal of Yunnan university, 2009 (4): 81-85.

[4] Liu Ming. The problem of human capital management in colleges and universities. Liaoning education research, 2004 (1): 50-51.

[5] Li Tao, Wang Chong. The human capital investment risk analysis and preventive measures. Price monthly magazine, 2006 (10): 43-44. 